International Congress for the History of Science

THE arrangements for the Fourth International Congress for the History of Science, to be held in Prague on September 22-27, are proceeding. The President of Czechoslovakia, Dr. Eduard Beneš, has agreed to give his patronage, and with him are Dr. Em. Franke, Minister of Education, Dr. Kamil Krofta, Minister of Foreign Affairs, Dr. Josef Zadina, Minister of Agriculture, the rectors of the Czechoslovak universities and corresponding schools, the presidents of the academies of science and of the scientific societies of Czechoslovakia, and the Chief Mayor of Prague. On the Committee of Honour, prominent leaders in industry and science in Czechoslovakia are represented. For the plenary meetings lectures have been promised by Prof. B. Nermec, formerly rector of the Charles University, president of the National Research Council of Czechoslovakia; Prof. O. Grosser, formerly rector of the German University in Prague; Prof. K. Studnička, of the Charles University; Prof. Gino Loria, of the University of Genoa, formerly president of the International Academy for the History of Sciences; Prof. Abel Rey, of the Sorbonne, director of the Institute for the History of Sciences and Technics. About a hundred papers, from Czechoslovakia and from Belgium, England, France, Germany, Italy, Poland, Portugal, Rumania, U.S.S.R., and Yugoslavia, have already been received. Members of the Congress will enjoy reductions on the railways of Czechoslovakia and of the other countries interested. Further information can be obtained from the general secretary of the Congress, Prof. Fr. Ulrich, Albertov 6, Praha II.

\section{Institute for Research in Metals, Sendai}

Prof. Kôtarô Honda has lately completed his twenty-fifth year as professor of physics in the Tohoku Imperial University, and the occasion has been commemorated by the publication of a special volume of the Science Reports of that University, contributed by his pupils and by friends from many countries. This substantial volume, of 1,126 pages, is an indication of the prominent part that Prof. Honda has played as teacher and also as director of the very active Institute for Research in Metals at Sendai. As might be expected from the special interests of Prof. Honda, from his work at Göttingen onwards, many of the papers, some sixteen in all, deal with the magnetic properties of metals, but the work of the Institute has covered a wide field in metallurgy, and most branches of the physical study of metals are represented. Another group treats of transformations of alloys in the solid state including steels. The development of improved steels for permanent magnets has been one of the most important results of the investigations at Sendai, the discoveries made there having had profound industrial effects, through reducing the size of magnets and even of enabling them to take the place of electromagnets in macbine tools, etc. Terrestrial magnetism is also represented, whilst other papers describe investigations in chemistry. Many well-known names are to be found among the contributors, and the occasion has been used to present surveys of the position of knowledge concerning several of the properties of alloys of current interest.

\section{Transmission of Electricity in France}

AN instructive lecture was given by $\mathbf{P} . \mathbf{M}$. $J$. Ailleret to the Transmission Section of the Institution of Electrical Engineers on April 29, the subject of the discourse being recent developments of electric transmission in France. The French system includes lines operating at $110,120,150$ and $220 \mathrm{kV}$. The reason for this difference is partly historical and partly geographical. The grid was begun in France in 1920, the pressure used being $120 \mathrm{kV}$.; a few years later it was considered necessary to raise it to $150 \mathrm{kV}$., and the first $220 \mathrm{kV}$. line was erected five years ago. Every time a new line was proposed which did not interest existing producers, a new company had to be formed, and the whole system was financed by the co-operation between producers, distributors and interested industries. No less than thirty-nine companies were formed to finance the construction of the lines, but the responsibility for operation is entrusted to a fairly small number of them. Another reason for the use of several voltages is that in France the price of coal varies much more from one part of the country to another than it does in England. Hydro-electric generation is concentrated in limited mountain areas and nearly half the total production comes from this source. Some regions which are rich in water power have practically no local consumers, others have an important electrochemical and electrometallurgical load, constant during the day, but with seasonal fluctuations which are advantageously combined with the usual loads of a distribution system. For these reasons a voltage of $220 \mathrm{kV}$. has in some cases been necessary. An eleven mile underground cable at this voltage was found necessary to transmit the energy from the south-east to the St. Denis power station through a densely populated suburban area. This oil-filled cable can carry 150,000 kilovolt-amperes.

\section{Fishing Gear}

THE third edition of "An Account of the Fishing Gear of England and Wales" (H.M. Stationery Office. $6 s$. net), has recently been issued, since the first publication in 1923, a fact which bears full witness to its value. The subject is a vast one, for $\mathrm{Mr}$. Davis's account ranges from the single hook handline to the modern otter trawl, from the whelk-pot to the fish weir nearly a quarter of a mile long. The most important modern fishing gears-otter trawl and drift net-are dealt with in detail, and the methods of shooting, fishing and hauling clearly explained. In this connexion it may be mentioned that many east coast drifters now shoot mackerelnets forward, rather than over the stern. There is a section on the Danish plaice seine, and Mr. C. F. Hickling has rewritten the account of the VigneronDahl trawl. Many of the instruments of the inshore 
fisherman described are now disused, or obsolescent, so that parts of the account are chiefly of historic interest. It is interesting to see how similar types of net have been evolved by fishermen on different parts of the coast, and how one type of net grades into another. The author points out that the Saltash tuck-seine is practically a trawl, and the Beer 'flybacked otter trawl' a seine. The braiding and setting of nets and their preservation is dealt with. Indeed, the use of Mr. Davis's paper would make clear any reference to the methods of fishing around the British coasts, or the description of the shape and construction of any net.

\section{St. Kilda Papers I93I}

A Publication entitled "St. Kilda Papers 1931" has just been issued, and contains, in addition to a foreword, bibliography and large-scale map, reprints of eleven papers previously published in various scientific journals. These papers, which deal with the mice, the breeding birds, the early autumn migration in 1931, the St. Kilda wren, the Coleoptera, the flora and the vegetation of St. Kilda, comprise the chief scientific results of an expedition to the island in the summer of 1931, the year following the evacuation of the islanders. As "St. Kilda Papers 1931 " is limited to an edition of only fifty copies, none is available for sale; but as the publication is intended as a basis for any future scientific work on the island, twenty-five copies have been presented to leading public libraries and to the libraries of learned scientific societies for reference purposes. Any further information relative to this publication or to the deposition of the library copies can be obtained from Mr. Malcolm Stewart, Hawridge Court, Nr. Chesham, Bucks.

\section{The World Power Conference}

WE have received a summary of the annual report for 1936 of the World Power Conference, prepared by the Central Office, 36 Kingsway, London, W.C.2. The chairman is Sir Harold Hartley (Britain) and the vice-chairmen are O. C. Merrill (United States), G. T. T. Bakker (Netherlands) and M. Kamo (Japan). The plenary conference was held in Washington on September 7-12, 1936, and was attended by about 3,000 members from fifty-four countries. Year book No. 1 was published in October 1936, and it is hoped that No. 2 will be published in September next. Statistics on manufactured gas and coke will be added in this and subsequent year books. The work of the international sub-commission on special cements is going steadily forward, and work on an international technical dictionary in connexion with dams will soon be begun. The International Executive Council has unanimously accepted the invitation of the German National Committee for the second chemical engineering congress to be held in Berlin in 1940. There is little doubt that the fourth World Power Conference will take place in 1942, thus preserving the interval of six years between successive plenary meetings.

\section{University of Lausanne}

Tнe fourth centenary of the University of Lausanne was celebrated on June 4-5, when honorary degrees were conferred on the following, among others: Sir Maurice Amos, Quain professor of comparative law in University College, London (Doctor of L.aws); Sir Frederick Gowland Hopkins, Sir William Dunn professor of biochemistry, in the University of Cambridge (Doctor of Medicine, in absentia); Prof. G. Barger, professor of chemistry in relation to medicine in the University of Edinburgh (Doctor of Pharmacy); and Prof. G. Rudler, Foch professor of French in the University of Oxford (Doctor of Letters). The University of Lausanne began in 1537 as the first college for the training of Protestant ministers, and other faculties were added during the nineteenth century.

\section{National Baby Week}

The National Baby Week Council announces that National Baby Week will be held on July 1-7. The theme selected for discussion and publicity this year is "Housing and Home in Relation to Maternity and Child Welfare", and a housing manifesto has been issued embodying certain ideals and ideas that may serve as a basis for discussion. This and other particulars may be obtained on application to the Secretary at 117 Piceadilly, London, W.1.

\section{Announcements}

THE University of Athens, on the occasion of its centenary celebrations, has conferred on Prof. F. G. Donnan, University professor of chemistry in University College, London, the honorary degree of D.Sc.

Mr. Edgar P. Chance, of Bulwell, Burchetts Green, near Maidenhead, has arranged a second exhibition of his collection of British birds' eggs to be held at the above address on June 25-26. The exhibition comprises about 150 drawers or trays selected from Mr. Chance's collection. Admission, from 10 a.m. until 8 p.m., is free.

A Conference on Magnetism will be held in the Physics Department of the University of Manchester on July 1-2, under the auspices of the Manchester and District Branch of the Institute of Physics. Prof. W. L. Bragg, the chairman of the Branch, will preside over the Conference and the following will give lectures: G. Richer, D. A. Oliver, Prof. N. F. Mott, Dr. C. Dannatt, Dr. E. C. Stoner, and Dr. A. J. Bradley. Visitors will be welcome, and further particulars may be obtained from Dr. C. Sykes, Research Department, Metropolitan-Vickers Electrical Co., Ltd., Trafford Park, Manchester, 17.

The fifty-sixth annual meeting of the Society of Chemical Industry will be held at Harrogate on July 5-9 under the presidency of the Right Hon. Lord Leverhulme. Prof. G. G. Henderson, recipient of the Society's Medal, will give an address entitled, "A Retrospect; Notes on some Development in the (Continued on p. 1063) 